\title{
气象部门财务管理探究
}

\author{
谭修敏 苏华 张楠 孙奇 付扬 张春渤 \\ 朝阳气象局 \\ DOI:10.32629/ej.v2i4.219
}

[摘 要] 目前, 国家正值改革窗口期, 随着国家财税体制改革的深入,气象业务、服务、管理体制改革对财务管理工作提出了更 高的要求。本文通过对新形势下气象部门财务管理的背景和现状的分析,围绕如何加强财务监管、规范财务运行等财务管理 思路,进行了探讨。

[关键词] 气象部门; 财务管理; 问题; 措施

气象部门作为国家公益性、基础性事业单位, 它既要考 虑自身的收益, 更要考虑社会公益性。它的资金来源的复杂 性, 以及当前以智慧气象为理念的四大体系建设, 决定了在 当前的新形势下,气象部门的财务管理工作面临新的挑战。

\section{1 气象部门财务管理常见的问题}

1. 1财务内控体系健全性不足

气象部门的财务内控体系尚不健全, 对财务活动未能实 施全面管控, 导致气象部门面临着一定的财务风险。如, 气象 部门财务内控制度建设相对滞后, 在一定程度上弱化了内部 监督审查力度; 气象部门受人员编制的影响, 导致基层单位 财务部门工作人员配置不足, 经常出现一人身兼多职的情况, 负责记账工作的会计人员还同时负责审核及档案保管等工 作, 难以形成相互牵制的岗位关系, 易滋生舞弊风险。

\section{2预算管理效率不高}

从近几年气象部门实施预算管理的现状来看, 却普遍存 在着预算执行效率偏低, 预算执行进度偏慢的问题, 弱化了 预算管理的职能作用。造成这种现象的原因首先是在预算的 编制过程中往往只有本单位财务部门参与, 其他部门参与的 较少, 这就使得所编制的预算往往与各部门的实际情况有偏 差; 其次是对项目的前期准备工作不够充分, 特别一些基建 项目涉及征地、拆迁等工作没有提前跟当地相关部门沟通; 再次在预算编制时间上, 受预算下达和上报时间紧迫的影响, 预算编制人员未能很好的跟各单位各部门沟通了解, 造成预 算编制质量不够高, 从而加剧了所编制预算与实际情况的偏 差, 降低了单位的预算管理水平。

1.3 固定资产管理有待提升

气象部门在固定资产管理上, 也存在一些亟需解决的问 题。首先, 在固定资产购入管理方面, 对准备购入的固定资产 缺乏合理的可行性分析, 从而导致固定资产在购入后其效用 的发挥并不理想; 其次, 在固定资产的日常管理上, 对固定资 产缺乏定期的清查盘点。根据固定资产管理要求, 事业单位 应定期 (一般为一年) 对固定资产的实物数量进行盘点、核 对。但是在基层气象部门, 由于人员配置原因、部门之间的 分工原因, 不能实现对固定资产的定期盘点, 盘点的间断和 滞后造成固定资产使用过程中出现的问题难以及时发现, 进
而造成处理问题的时间滞后。再次, 在固定资产处置方面, 气象部门基层单位由于人员配置原因, 对固定资产维修、报 废、处置等不及时入账, 也没有及时在固定资产管理系统上给 予相应调整, 从而导致固定资产管理存在着一定的滞后性。

\section{4财务人员素质有待提升}

随着事业单位改革的不断推进, 财务风险随之增大, 这 对气象部门财务人员综合素质提出了更高的要求。但是, 气 象部门基层财务人员的业务能力有限, 大部分基层气象部门 在配备财务人员时, 只是调配其他专业人员任职财务工作岗 位, 他们对财务业务并不熟悉, 造成财务管理工作质量不高, 缺乏丰富的工作经验, 难以履行财务管理职责。同时, 气象部 门较少对基层财务人员教育与培训, 使得年轻的财务人员缺 乏职业判断能力和实务操作能力, 影响会计信息质量。

\section{2 解决气象部门财务管理问题的措施}

2.1 建立健全财务内控制度

财务内控制度是对财务活动进行全面监督、检查和控制 的重要依据。气象部门要建立健全财务内控制度, 针对新时 期下国家对事业单位财务管理提出的要求, 优化财务内控流 程, 提高气象部门财务管理工作水平。气象部门要以遵循国 家财经法律为前提, 结合本单位实际情况完善财务内控制度, 增强制度执行刚性, 并定期对财务内控制度执行情况进行评 价, 落实相应的改进措施。气象部门的财务内控制度应包括 岗位责任制度、大额支出管理制度、民主决策制度、预算管 理制度、资产管理制度等, 明确各部门在财务内控中应承担 的责任, 充分发挥财务控制的作用, 降低财务风险。

\section{2构建预算管理体系}

预算管理是财务管理的重要内容, 对有效控制资金支 出、优化资源配置起着积极作用。为此, 气象部门应建立起 完善的预算管理体系, 落实责任预算。在预算编制中, 预算编 制人员应综合考虑上一年度预算执行情况、行业发展状况以 及中长期目标编制预算, 在做好项目论证、调查研究、目标 预测等工作的基础上, 合理规划预算编制时间, 保证编制时 间充足。气象部门要对本单位的定额指标、综合指标进行分 析研究, 调动起单位内部各个部门参与预算编制的积极性, 确保预算编制与实际执行情况相符。在预算执行过程中, 气 
象部门应该根据本单位的项目预算情况, 提前做好前期准备 工作, 在预算额控制数已下达的情况下, 单位内部的各部门 要明确责任, 合理分工, 相互配合做好项目的立项、招投标工 作。气象部门要根据预算控制各项支出, 并对预算执行过程 进行监督考核, 及时发现和解决预算执行问题。预算执行完 毕后, 要分析预算从编制到执行整个过程中出现的问题, 实 际情况与预算不相符的, 分析产生问题的原因, 同时将预算 执行情况纳入各部门的业绩考核, 气象部门要将预算考核 结果作为下一年度预算编制的依据, 同时针对各部门的考 核评价结果落实相应的奖惩措施, 形成全员参与预算管理 的氛围。

\section{3落实全过程财务监督}

气象财务部门要全面落实财务监督职能, 定期召开财务 监督汇报会, 汇报本部门的财务活动情况。气象部门应在内 部设置财务稽核岗, 配备高素质财务稽核人员, 对本单位财 务活动进行稽查监督, 杜绝出现舞弊、违规行为。在财务稽 核工作中, 要对财务收支数据的合理性和合法性进行审核, 对财政资金的使用过程进行跟踪监督, 并且检查财务内控系 统执行的有效性, 保证本单位各项财务活动均在合法合规的 范围内开展。同时, 气象部门还要充分发挥内部审计职能, 客观评价财务内控的执行情况, 检查财务工作是否存在疏漏, 进一步完善财务管理体系。此外, 上级主管部门要重视对气 象部门财务工作的监督检查, 尤其针对政府采购、固定资产 管理、预算管理等方面加大检查力度, 督促气象部门及时整 改不规范之处, 监督气象部门不断完善财务管理体系。

2. 4加强财务人员素质培养
目前, 气象部门基层专业专职财务人员紧缺, 业务素质 有待提高, 各单位要高度重视财务工作, 积极创造条件通过 招聘和选拔专业财务人员充实财务工作队伍, 将其作为提高 财务管理水平的一项重要工作, 不断提升财务人员的专业素 质。首先, 气象部门要对财务人员开展职业道德教育, 使财务 人员严明财经法纪, 在开展财务工作的过程中始终保持清醒 的头脑, 认清履行自身职责。其次, 气象部门要组织财务人员 定期参加业务培训, 掌握最新的财税政策, 提高常规业务处 理能力, 并通过业务竞赛、交流研讨等形式促进财务人员不 断提升业务水平, 夯实会计基础工作。再次, 气象部门要优化 财务人员结构, 积极引入和培养复合型财会人员, 使财会人 员能够胜任财务核算、财务监督、财务决策、财务预测、财 务控制等各项工作, 满足气象部门实施精细化财务管理的要 求, 促进气象部门财务管理水平不断提升。

\section{3 结语}

气象部门的财务管理工作要坚持公共气象发展方向, 全力保障气象现代化建设, 在提高发展质量和效益上下工 夫, 在改革创新上下工夫, 全面提升整个部门财务的科学管 理水平。

\section{[参考文献]}

[1]王诗琦,周慧僚,黎慧娟.气象部门财务精细化管理的 意义和方法[J].纳税,2017(14):35。

[2]徐飞英,王珏.气象部门会计集中核算体制下财务管 理的探索[J].财会学习,2017(24):49-50.

[3]李楠.新形势下做好气象部门财务管理工作的几点思 考[J].财政监督,2017(17):103-106. 